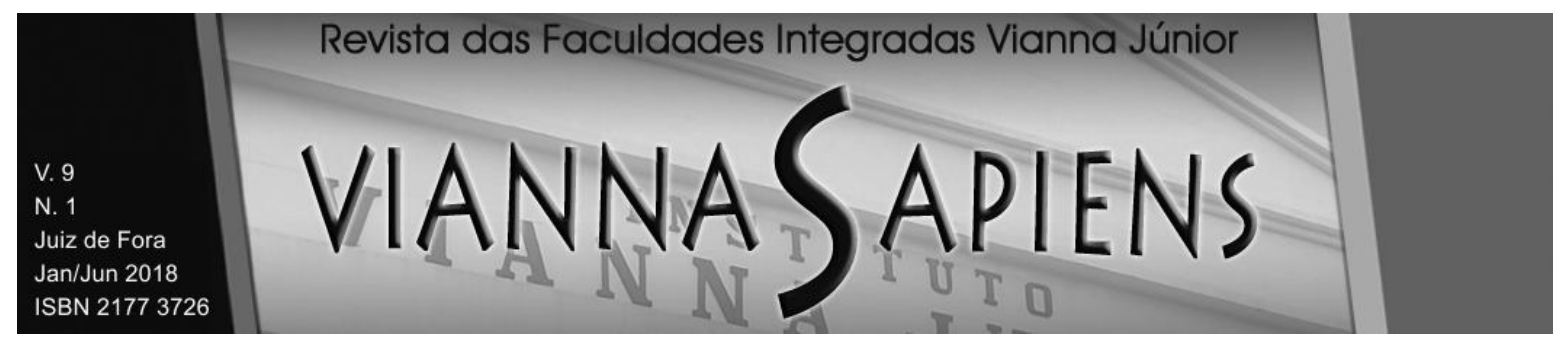

\title{
A (IM) POSSIBILIDADE DE APLICAÇÃO DA TEORIA DA CEGUEIRA DELIBERADA NO DIREITO PENAL BRASILEIRO \\ DOI: 10.31994/rvs.v9i1.353
}

Aline Guelli Correia ${ }^{1}$

Gabriel Senra e Pádua ${ }^{2}$

\section{RESUMO}

O presente artigo visa o estudo da Teoria da Cegueira Deliberada e sua possibilidade de aplicação no ordenamento jurídico brasileiro. De início busca-se esclarecer a origem histórica, nomenclaturas, conceitos e delimitações da Teoria. Após estas considerações, passa-se a abordar sobre o dolo no direito penal brasileiro e as controvérsias existentes sobre a Teoria no âmbito da inexistência do dolo. Por fim foi apresentada uma breve explicação sobre a Lei de Lavagem de Capitais, com a análise dos principais casos em que a Teoria foi aplicada em nossos Tribunais. Em conclusão o objetivo deste trabalho foi abordar a Teoria da Cegueira Deliberada de maneira mais específica, restringindo-se ao Direito Penal Brasileiro, verificando a possibilidade de aplicação em nosso ordenamento jurídico, bem como as controvérsias doutrinárias e jurisprudências sobre o assunto.

PALAVRAS-CHAVE: TEORIA DA CEGUEIRA DELIBERADA. DOLO EVENTUAL. LAVAGEM DE CAPITAIS. DIREITO PENAL BRASILEIRO

${ }^{1}$ Bacharel em Direito pelo Instituto Vianna Júnior. Advogada. E-mail: alineguelli@gmail.com. ORCID ID: https://orcid.org/0000-0002-4398-4615.

2 Mestre pela Universidade Presidente Antônio Carlos. Advogado. E-mail: gabriel79.jf@gmail.com. ORCID ID: https://orcid.org/0000-0003-1191-103X 


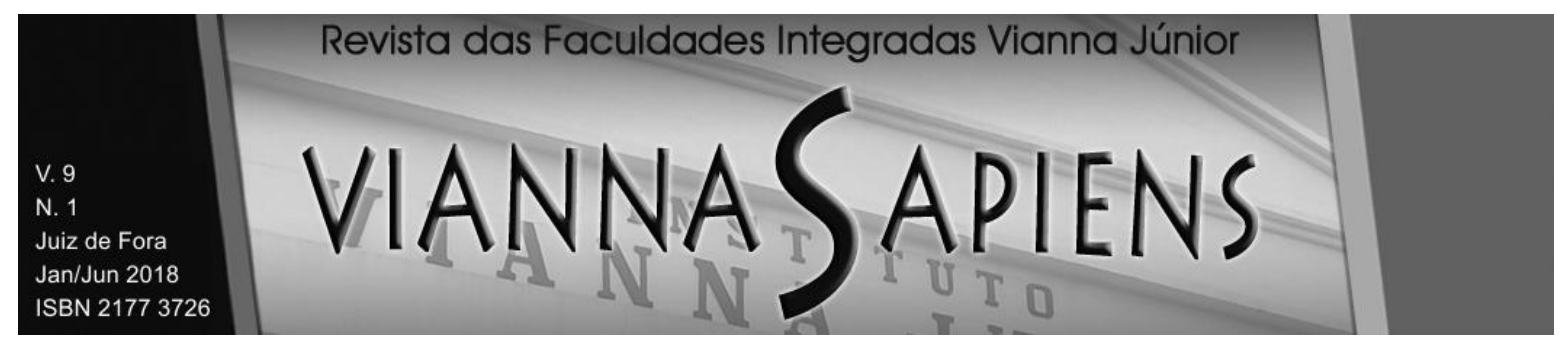

\section{INTRODUÇÃO}

Tradicionalmente o Brasil é adepto da Civil Law, sistema que respeita a preponderância da norma, admitindo de forma excepcional o uso dos precedentes diante de lacunas na lei. A Teoria da Cegueira Deliberada mostra-se necessária nos casos em que o Poder Judiciário encontra esta lacuna.

A Teoria tem origem no ordenamento jurídico inglês, através de entendimentos jurisprudenciais (Common Law), sendo reconhecida no meio jurídico por diversas denominações, como Doutrina da Cegueira Intencional e Teoria das Instruções da Avestruz.

A Doutrina da Cegueira Intencional é aplicada em diversos ordenamentos jurídicos, contudo ainda não há uma uniformidade quanto aos seus pressupostos, teses e decisões. A Teoria recentemente passou a ser utilizada no Direito Penal Brasileiro, com maior aplicação no crime de lavagem de capitais, mas também é adotada em outras modalidades de crimes, tais como estelionato, peculato, sonegação fiscal, tráfico de drogas e corrupção eleitoral. Ela não versa sobre um tipo penal específico, ela esta ligada ao elemento subjetivo do tipo penal, tendo em vista que para sua aplicação a atenção é voltada ao dolo do agente, para a teoria o indivíduo é punido pela ocorrência do dolo eventual.

Esta teoria foi criada para as hipóteses em que o agente, sabendo da tipicidade de sua conduta, coloca-se em situação de ignorância deliberada, na intenção de sair impune por tal ato. Em outras palavras, o sujeito ignora informações que poderia obter, atua ignorando dados penalmente relevantes, fruto de uma decisão consciente, no intuito de alegar posteriormente, desconhecimento de qualquer ilicitude.

No início deste trabalho, busca-se abordar a Teoria da Cegueira Deliberada de forma ampla, esclarecendo sua origem, suas diferentes nomenclaturas, bem como elucidando seu conceito e delimitações. 


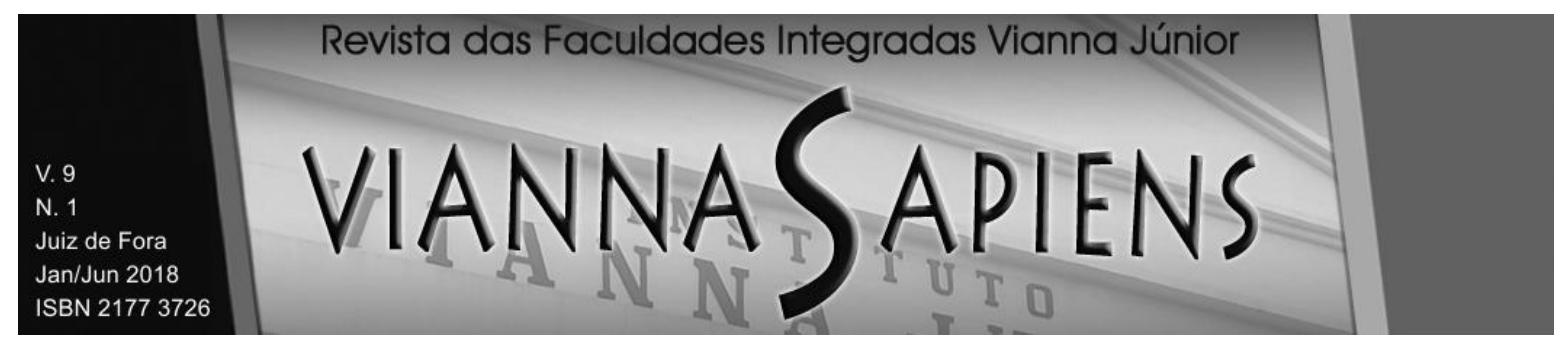

No segundo item será analisado o dolo no direito penal brasileiro, abordando seus elementos e espécies. Na parte final, tratou-se de críticas à doutrina, sob a visão de inexistência do dolo.

Ao final, será realizado um breve estudo sobre a recente modificação da Lei de Lavagem de Capitais, abordando a existência da Teoria na jurisprudência brasileira, apresentando os casos de maior repercussão em nosso país, que possibilitaram a aplicação da Teoria da Cegueira Deliberada, bem como sua aceitação no Direito Penal Brasileiro.

Desse modo, a presente pesquisa tem por objetivo abordar a Teoria da Cegueira Deliberada de maneira mais específica, restringindo-se ao Direito Penal Brasileiro, verificando a possibilidade de aplicação em nosso ordenamento jurídico, bem como as controvérsias doutrinárias e jurisprudências sobre $o$ assunto.

\section{A TEORIA DA CEGUEIRA DELIBERADA}

A Teoria da Cegueira Deliberada tem aplicação recente no ordenamento jurídico brasileiro, fruto de entendimentos jurisprudenciais ingleses e com ampla aplicação nos tribunais norte-americanos, surge no Direito Penal Brasileiro com o intuito de preencher lacunas na lei, contudo ainda há grande inconsistência entre jurisprudência e doutrina.

\subsection{Origem Histórica}

A Teoria da Cegueira Deliberada tem origem na Common Law, havendo divergências doutrinárias sobre seu surgimento. A Teoria teve ampla aplicação no ordenamento jurídico norte-americano, em casos de tráfico de drogas e crimes do colarinho branco, sendo posteriormente ampliada e utilizada em diversos casos.

Segundo Ira P. Robbins (1990, tradução nossa), a Ostrich Instructions surgiu na Inglaterra em 1861, no caso Regina vs. Sleep, sendo que o primeiro caso em que 


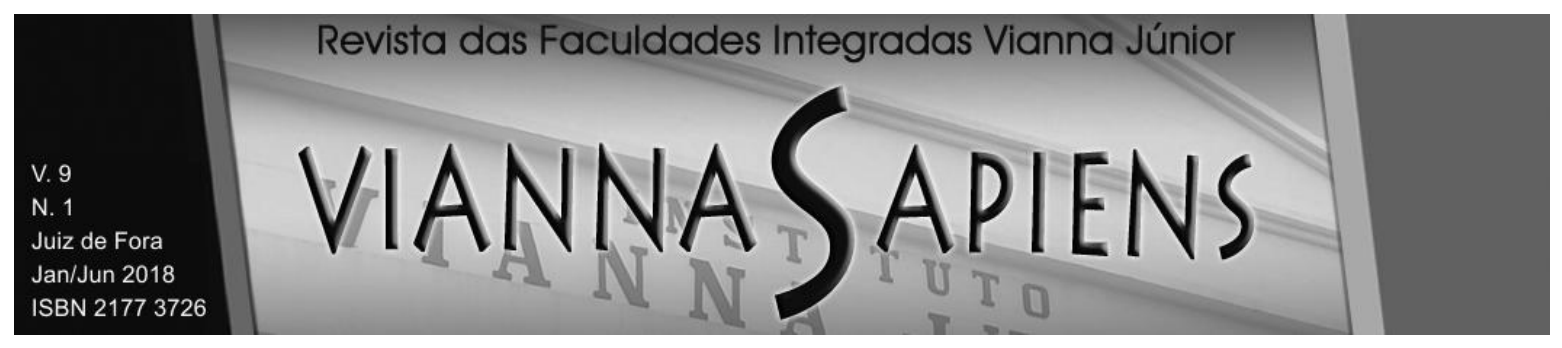

a teoria foi abordada no ordenamento norte-americano viria somente em 1887, em People vs. Brown ${ }^{3}$.

No caso Regina versus Sleep, Sleep era um ferreiro que foi acusado de posse não autorizada de bens do governo. Sleep embarcou em um navio com um barril que continha parafusos de cobre, alguns dos quais estavam marcados com o símbolo do governo britânico, indicando que eram de propriedade do governo. $\mathrm{O}$ conhecimento de que os parafusos estavam marcados com o símbolo do governo britânico era necessário para uma possível condenação, contudo houve dúvidas se Sleep identificou a marcação ou deliberadamente as ignorou ${ }^{4}$ (CHARLOW, 1992, tradução nossa).

Em 1899 a Willful Blindness aparece pela primeira vez na Suprema Corte dos Estados Unidos, no caso Spurr v. Estados Unidos. Em sua condenação Spurr foi condenado por certificar cheques emitidos por um cliente, cuja conta carecia de fundos. De acordo com a lei aplicável para punir criminalmente tal conduta era necessário uma violação intencional das regras que regem a emissão de cheques. A Suprema Corte entendeu que se o responsável certifica cheques com a intenção que o emissor obtenha dinheiro, mesmo não havendo fundos, tal certificação não é apenas ilegal, mas pode ser imputado ao mesmo o fim específico de violar a lei. Essa má intenção pode ser presumida quando o oficial mantém-se na ignorância deliberada quanto a existência de fundos ou quando demonstra indiferença

${ }^{3}$ The correlation between knowledge and deliberate ignorance initially emerged in England in 1861. Regina $v$. Sleep was the first case in which this equivalence received judicial approval. In American law, an early discussion of the doctrine occurred in People $v$. Brown, decided in 1887.

${ }^{4} \mathrm{Mr}$. Sleep, an iron monger, was charged with the unauthorized possession of government property. He had delivered a cask for shipment that contained copper bolts, some of which were marked with the British government's special broad Arrow sign, designating that they were government property.' Knowled get hat the bolts were marked with the especified government markings was required for conviction,' and there was some question as to whether Sleep had noticed or wilfully ignored the broad Arrow marks.' 


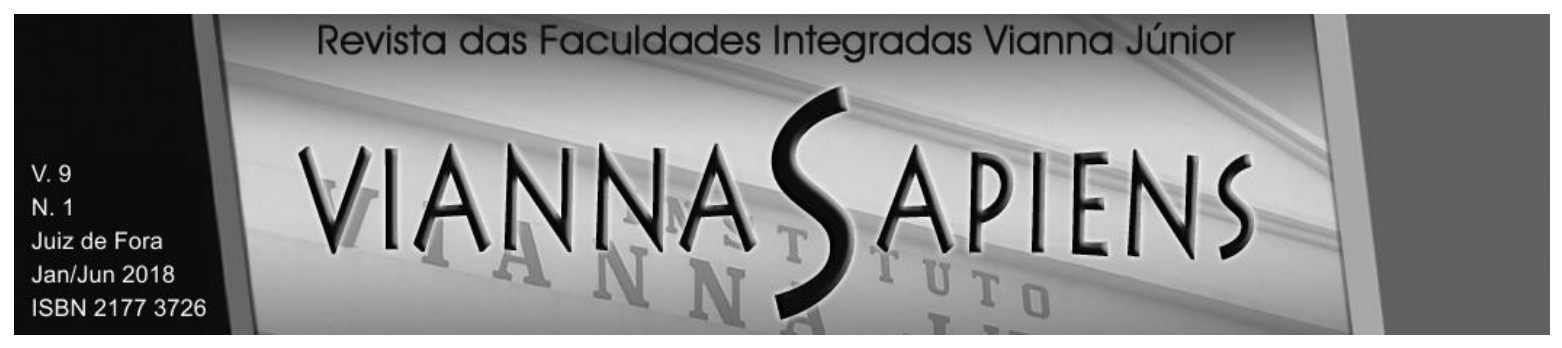

grosseira sobre seu dever de se assegurar acerca desta circunstância (GHER, 2012).

\subsection{Nomenclaturas}

Nas palavras de Bruno Fontenele Cabral (2012), a Teoria da Cegueira Deliberada é conhecida no meio jurídico por diversas denominações, tais como; Doutrina da Cegueira Intencional (Willful Blindness Doctrine), Teoria das Instruções da Avestruz, Doutrina do Ato de Ignorância Consciente (Conscious Avoidance Doctrine), Instruções de Avestruz (Ostrich Instructions), dentre outras.

Segundo Taiana Alves Monteiro (2009), o nome desta Teoria provém da seguinte explicação:

O nome dessa teoria provém exatamente do ato de um avestruz, qual seja, enterra sua cabeça na areia para que não veja ou escute más notícias, evitando assim, tomar conhecimento de fatos desagradáveis. É exatamente o que ocorre com a pessoa que finge não saber que está praticando um ato ilícito, "enterra" a cabeça para não tomar conhecimento da natureza ou extensão deste ilícito.

\subsection{Conceito e Delimitação}

A Doutrina da Cegueira Intencional foi criada para as hipóteses em que o agente, sabendo da tipicidade de sua conduta, coloca-se em situação de ignorância deliberada, na intenção de sair impune por tal ato. Em outras palavras, o sujeito esquiva-se de informações que poderia obter, atua ignorando dados penalmente relevantes, fruto de uma decisão consciente, no intuito de alegar posteriormente desconhecimento de qualquer ilicitude.

Em ROBBINS, 1990 (apud WILLIAMS, 1961, at. 159, tradução nossa) conceitua-se a teoria da seguinte forma:

Um tribunal pode corretamente encontrar cegueira intencional apenas onde pode quase ser dito que o réu realmente sabia. Ele suspeitava do fato; Ele percebeu sua probabilidade; Mas ele se 


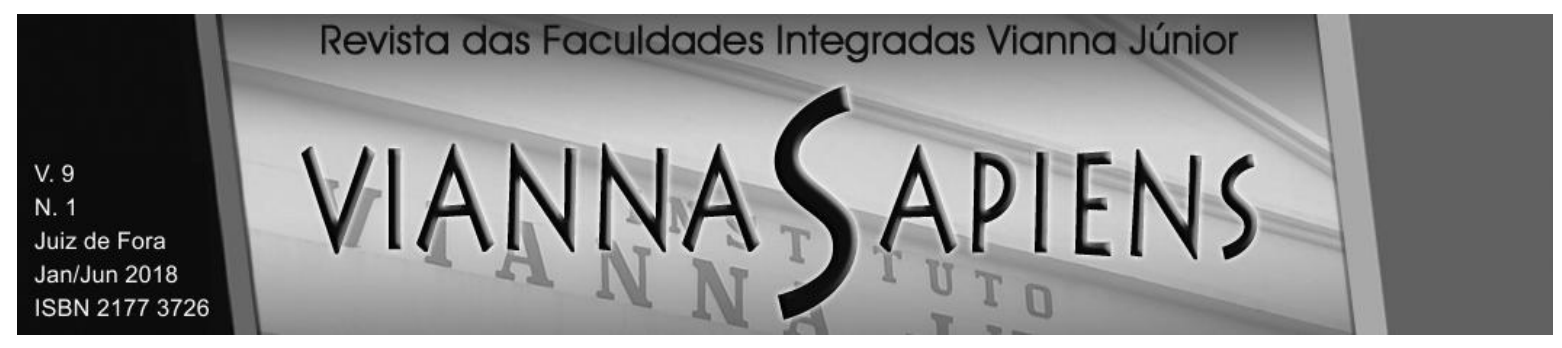

absteve de obter a confirmação final, porque ele queria no caso de ser capaz de negar o conhecimento. Isto, e só isso, é a cegueira deliberada ${ }^{5}$.

Esta teoria não versa sobre um tipo penal específico, ela esta ligada ao elemento subjetivo do tipo penal, para sua aplicação a atenção é voltada ao dolo do agente, para a teoria o indivíduo é punido pela ocorrência do dolo eventual.

De acordo com CABRAL, 2012 (apud ABRAMOWITZ \& BOHRER, 2007) a Teoria da Cegueira Deliberada busca a punição do agente que se coloca nesta situação, admite que haja uma condenação criminal mesmo diante da ausência da consciência plena do caráter ilícito, permitindo a presunção de conhecimento do acusado mesmo nos casos em que não há prova concreta do seu real envolvimento com a situação suspeita.

Ramón Ragués i Vallès estabelece três requisitos para o reconhecimento da cegueira deliberada. Em CALLEGARI e WEBER, 2017 (apud RAGUÉS I VALLÈS, 2007, p. 142-143) esclarece-se que o primeiro requisito diz respeito a suspeita justificada do agente sobre a concorrência de sua conduta à atividade, neste requisito pode-se dizer que não há uma representação plena do sujeito a respeito do fato, contudo ele deixa de obter a consciência voluntariamente, criando barreiras ao seu conhecimento.

O segundo requisito refere-se a disponibilidade da informação, informação esta que permitiria ao agente ter conhecimento do ilícito, sendo necessário que as informações estejam ao alcance do sujeito, sem maiores obstáculos.

O terceiro e último requisito refere-se a decisão do agente em manter-se na ignorância, "fechando os olhos" às informações disponíveis as quais tinha o dever de conhecer, ou seja, a intenção de manutenção do estado de ignorância para proteger-se de eventual descoberta do delito e possível condenação.

${ }^{5} \mathrm{~A}$ court can properly find wilful blindness only where it canal most be Said that the defendant actually knew. He suspected the fact; he realized its probability; but here frained from obtaining the final confirmation because he wanted in the event to be able to deny knowledge. This, and this alone, is wilful blindness. 


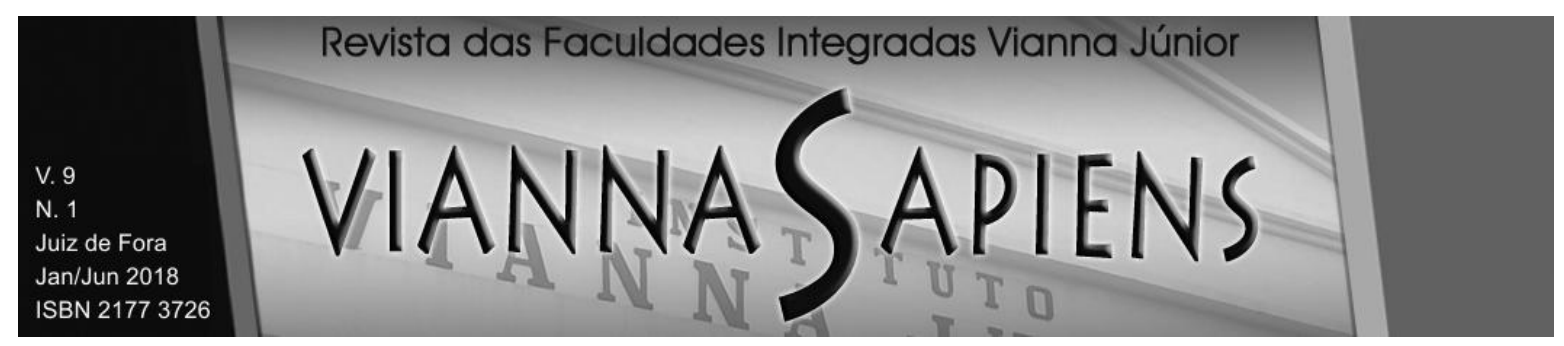

A doutrina é aplicada em diversos ordenamentos jurídicos, contudo ainda não há uma uniformidade quanto aos seus pressupostos, teses e decisões. A Teoria da Cegueira Deliberada passou a ser empregada no Direito brasileiro recentemente, nos crimes de lavagem de capitais, contudo já vem sendo aplicada em outras modalidades de crimes, tais como estelionato, peculato, sonegação fiscal, corrupção eleitoral e tráfico de drogas.

\section{ANÁLISE DO DOLO NO DIREITO PENAL BRASILEIRO}

No Direito Penal brasileiro o dolo é concebido pela Teoria Finalista de Hans Welzel. Os finalistas compreendem o crime como fato típico, antijurídico e culpável, para esta teoria dolo e culpa migram para o fato típico.

Na lição de Rogério Sanches Cunha (2016, p. 183):

Ao migrar para o fato típico, o dolo passa a ter dois elementos: consciência e vontade. O tipo, por sua vez, passa a ter duas dimensões: a dimensão objetiva (conduta,resultado, nexo e adequação típica) e a dimensão subjetiva, representada pelo dolo ou pela culpa.

Ao se destacar da consciência da ilicitude, alocada como elemento próprio na culpabilidade, o dolo perde o seu elemento normativo. Por este motivo é que, no finalismo, o dolo é natural (despido de valoração), é o dolus bonus. Contrapõe-se, portanto, à perspectiva causalista do dolo normativo, do dolus malus.

O dolo na concepção finalista é tratado como um elemento puramente psicológico. O dolo é natural, livre de qualquer elemento normativo, formado exclusivamente por elementos subjetivos, qual seja volitivo e intelectual.

O artigo 18 do Código Penal Brasileiro dispõe que o crime é doloso quando o agente quis o resultado ou assumiu o risco de produzi-lo. Conforme dispõe Cunha (2016, p. 193), o dolo é a vontade consciente dirigida a realizar, ou aceitar realizar, a conduta prevista no tipo penal incriminador. 


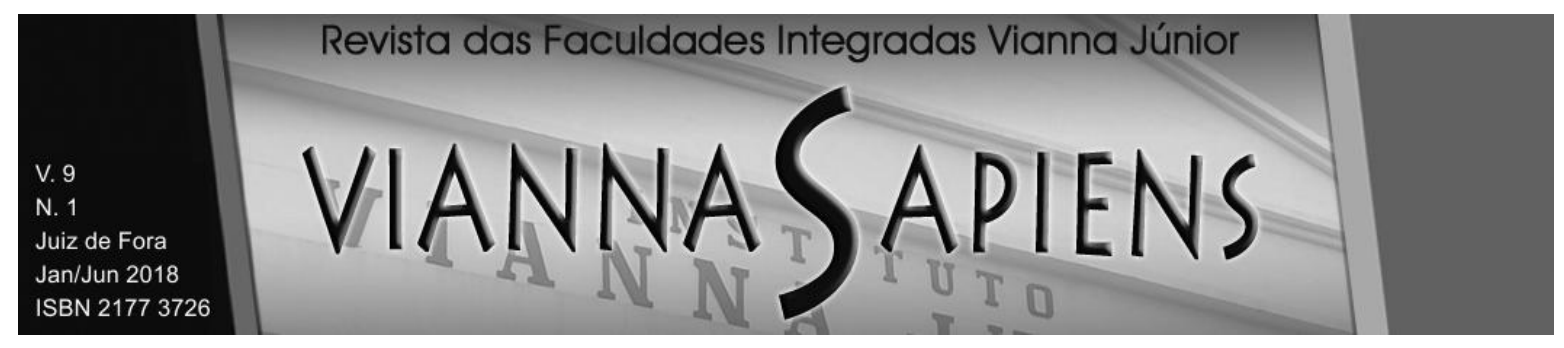

Com o estudo do artigo 18 do Código Penal conclui-se que é adotada a teoria da vontade para o dolo direto e a teoria do consentimento para o dolo eventual. Pela teoria da vontade há o dolo direto quando há vontade consciente em praticar a infração penal, pela teoria do consentimento / assentimento há dolo eventual quando o agente prevê o resultado como possível e persiste na prática delituosa, assumindo o risco de produzir o resultado.

\subsection{Espécies de Dolo}

O dolo pode ser direto ou indireto e de acordo com Paulo César Busato (2017, p.397) as espécies de dolo existentes apresentam uma diferenciação quantitativa:

O compromisso que se estabelece para com a produção do resultado pode derivar tanto de um desprezo quanto de uma pretensão a respeito de sua ocorrência, o que faz com que as diversas modalidades de dolo não sejam mais do que uma diferença em graus de desvalor do compromisso para com a produção do resultado. Ou seja, não existem dolos essencialmente diferentes, mas sim graus diferentes de desvaloração dolosa.

No dolo direto o agente busca intencionalmente o resultado, dirigindo sua conduta para o fim pretendido (teoria da vontade). $\mathrm{O}$ agente concentra sua vontade à realização do fato típico.

Nas palavras de Cezar Roberto Bitencourt (2017, p. 361):

O dolo direto compõe-se de três aspectos, quais sejam, representação, querer e anuir, nos seguintes termos: 1) a representação do resultado, dos meios necessários e das consequências secundárias; 2) o querer a ação, o resultado, bem como os meios escolhidos para a sua consecução; 3) o anuir na realização das consequências previstas como certas, necessárias ou possíveis, decorrentes do uso dos meios escolhidos para atingir o fim proposto ou da forma de utilização desses meios. 


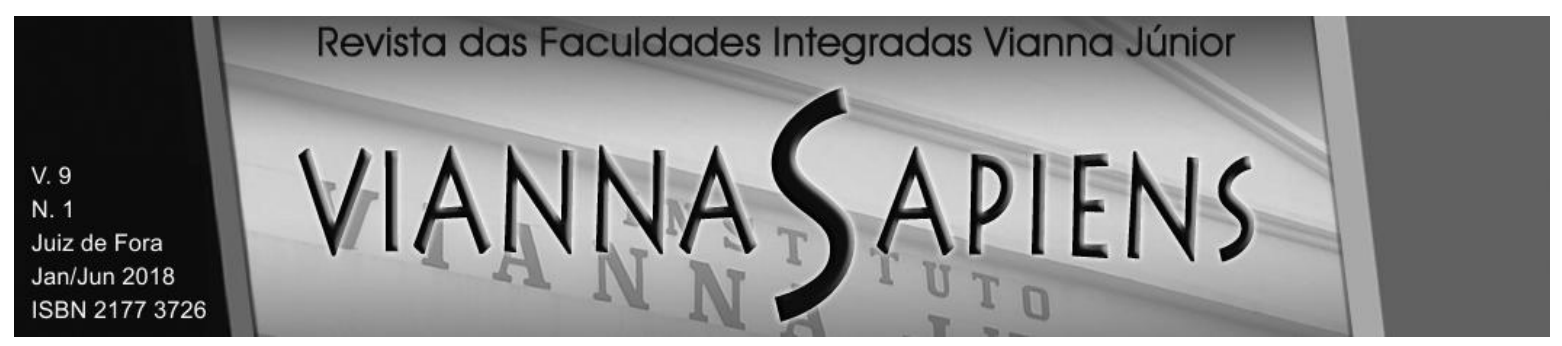

Haverá dolo eventual quando o agente não quer diretamente a realização do tipo penal, mas assume o risco de produzir o resultado (teoria do assentimento).

Assim dispõe Miguel Reale Jr. (2012, p. 225):

O dolo é eventual quando o agente inclui o resultado possível, de forma indiferente, como resultado da ação que decide realizar, assentindo em sua realização, que confia possa se dar.

Diante de um resultado nocivo possível, o agente arrisca e prefere agir, admitindo e não the repugnando, assim, a ocorrência do resultado.

\subsection{Erro de Tipo e Teoria da Cegueira Deliberada}

Pierpaollo Botini (2012), em recente artigo, equipara a cegueira deliberada a uma situação proposital de erro de tipo. É possível encontrar em doutrinas, estudiosos que compreendem a Teoria da Cegueira Deliberada como uma interpretação extensiva, caracterizando-a em analogia in mallam partem.

Nesse sentido expõe Vinicius Arouck (2017):

A construção jurisprudencial da Teoria da Cegueira Deliberada nada mais é que uma interpretação extensiva do conceito de dolo, pois, uma vez que o dolo é conceituado na parte geral do Código Penal Brasileiro como querer e conhecer, não pode o intérprete da lei (o juiz) considerar um eventual não conhecimento de determinado pressuposto fático, por qualquer razão que seja, como conhecimento para fundamentar um decreto condenatório.

O erro sobre o elemento do tipo está previsto no art. 20 do Código Penal, e determina a ausência de dolo, consistindo no desconhecimento do autor acerca dos elementos constitutivos do tipo presentes em sua conduta.

Diante das breves explicações CALLEGARI e WEBER (2017, p. 186-187) possibilitaram o seguinte entendimento acerca da diferenciação entre o erro de tipo e a teoria da cegueira deliberada:

Da breve exposição acerca do erro, não há como alegar que a teoria da cegueira seja sua modalidade, uma vez que, admitindo-se tal 


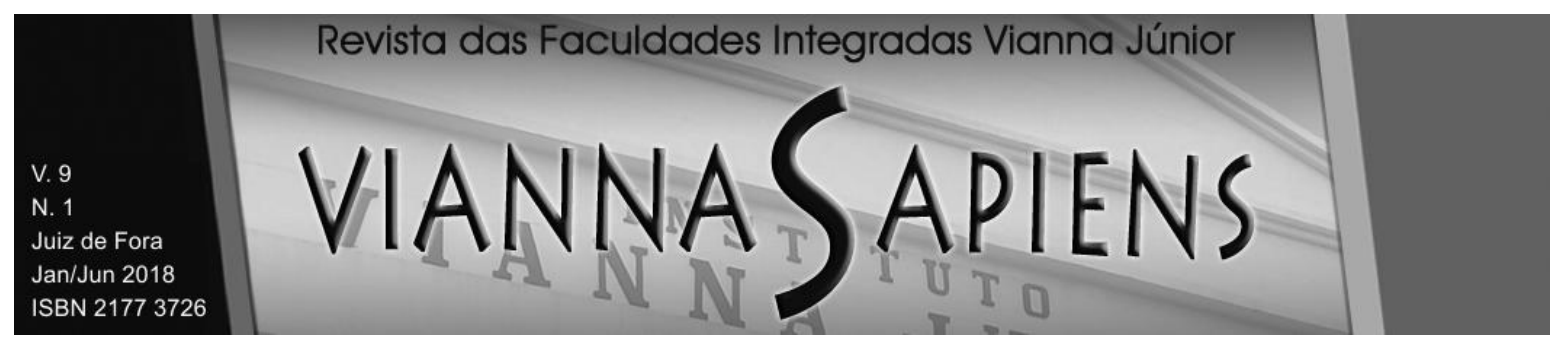

possibilidade, estar-se-á punindo o indivíduo sem que haja o dolo exigível. Em verdade, a cegueira deliberada, como já mencionado, exige a firme convicção da possibilidade de crime, contudo, há uma ação positiva do agente para evitar chegar ao conhecimento pleno. No erro de tipo, não há sequer representação do elemento típico do delito, excluindo o dolo.

Deste modo compreende-se que o desconhecimento determinado pela Teoria da Cegueira Deliberada não se configura erro de tipo, pois em concordância com o que foi demonstrado, o sujeito, na cegueira intencional tem acesso aos elementos constitutivos do tipo, mantendo-se em ignorância propositalmente.

\subsection{Responsabilidade Penal e a Teoria da Cegueira Deliberada}

O Direito Penal Brasileiro adota atualmente a Teoria Finalista da Ação de Hanz Welzel, reconhecendo expressamente em seu artigo 18 que os crimes são dolosos ou são culposos.

Neste sentido entende-se que em nosso ordenamento jurídico aplica-se a responsabilidade penal subjetiva, no qual o agente apenas será responsabilizado criminalmente nos casos de dolo ou culpa. Em Capez (2016, p. 143) encontramos o seguinte esclarecimento:

Ao Direito Penal não interessam os resultados produzidos sem dolo ou culpa, porque sua razão maior de existir funda-se no princípio geral da evitabilidade da conduta, de modo que só se devem considerar penalmente relevantes as condutas propulsionadas pela vontade, pois só essas poderiam ter sido evitadas.

Diante do entendimento que nosso ordenamento jurídico adota a Responsabilidade Penal Subjetiva, surgem posicionamentos contrários a aplicação da Teoria da Cegueira Deliberada no Direito Penal Brasileiro, sob a justificativa que sua aplicação geraria a legitimação da Responsabilidade Penal Objetiva, por entenderem que a Teoria se utilizaria de um tipo penal específico, responsabilizando o agente independente de dolo ou culpa. 


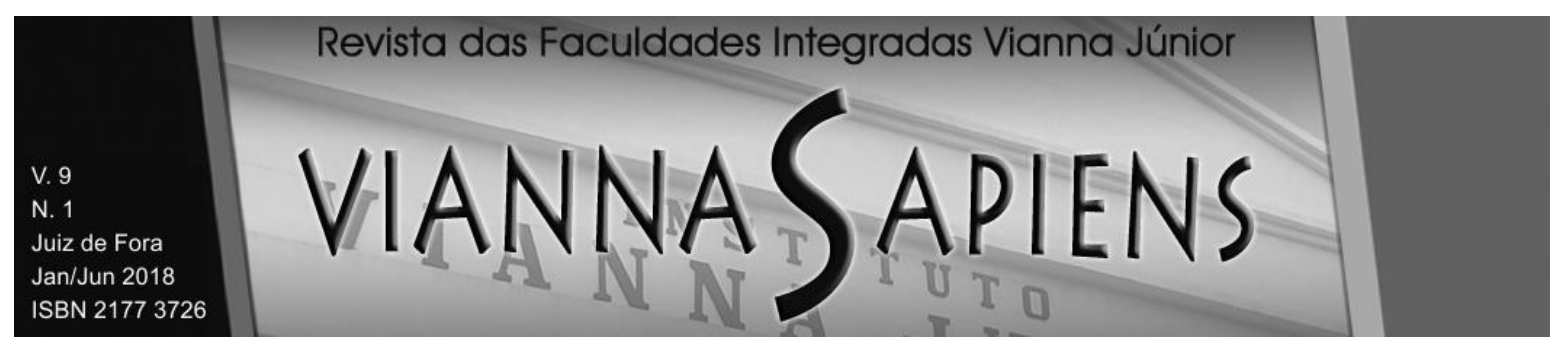

Neste sentido foi o entendimento do Tribunal Regional Federal da 5 $5^{\mathrm{a}}$ Região, na Apelação Criminal 5.520-CE (2008), no Caso do Furto ao Banco Central de Fortaleza:

(...) a transposição da doutrina americana da cegueira deliberada (willful blindness), nos moldes da sentença recorrida, beira, efetivamente, a responsabilidade penal objetiva; não há elementos concretos na sentença recorrida que demonstrem que esses acusados tinham ciência de que os valores por ele recebidos eram de origem ilícita, vinculada ou não a um dos delitos descritos na Lei n. ${ }^{\circ} 9.613 / 98$. O inciso II do $\S 2 .^{\circ}$ do art. 1.. dessa lei exige a ciência expressa e não, apenas, o dolo eventual. Ausência de indicação ou sequer referência a qualquer atividade enquadrável no inciso II do $\S \S 2^{\circ}$.

O professor Vinicius Arouck (2017), em recente artigo, atenta que a aplicação da Teoria da Cegueira Deliberada, em certas ocasiões, enquadra-se na há muito tempo combatida Responsabilidade Penal Objetiva.

Em conformidade com todo o exposto neste trabalho, convém ressaltar que a Teoria da Cegueira Deliberada não versa sobre um tipo penal específico, ela se relaciona ao elemento subjetivo do tipo penal, voltando seus olhos para o dolo do agente, a Teoria aplica-se com base no dolo eventual.

Diante disso, observa-se que a Teoria ainda sofre severas críticas quanto a sua aplicação em nosso ordenamento, sendo de extrema importância que se aprofunde e delimite seus critérios, esquivando-se de uma aplicação com base em mera suposição de ignorância deliberada, sem a devida fundamentação jurídica, o que causaria inevitavelmente a configuração da Responsabilidade Penal Objetiva.

\section{APLICAÇÃO DA TEORIA DA CEGUEIRA DELIBERADA NO BRASIL}

A Teoria da Cegueira Deliberada consoante ensinado por Ira P. Robbins (1990), surgiu em 1861 na Inglaterra, fruto de entendimentos jurisprudenciais (Common Law). Após alguns anos a teoria também foi aplicada no direito Norte- 


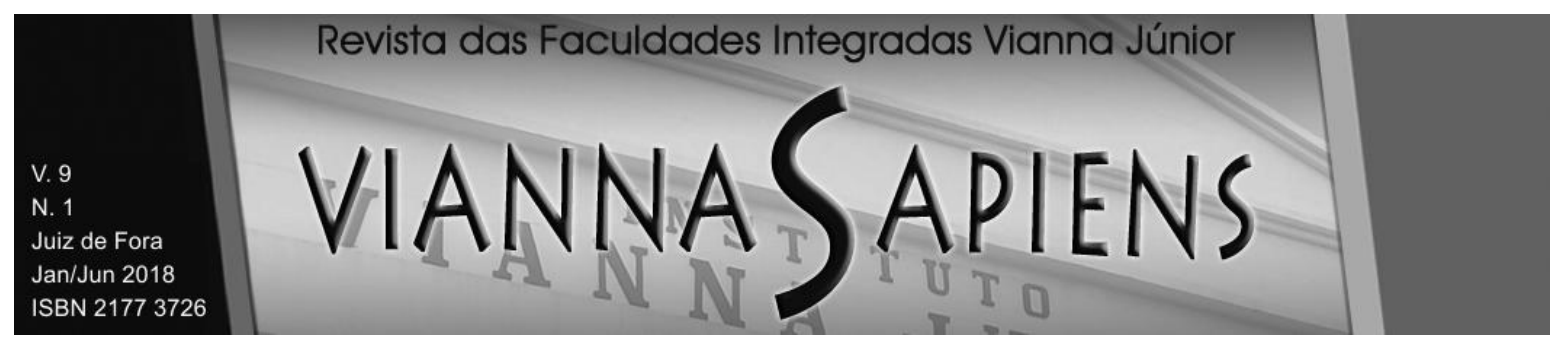

americano, sendo possível apontar diversos julgamentos da Wilfull Blindness nos Tribunais Ingleses e Norte-americanos.

No cenário brasileiro, observa-se a aplicação da Teoria da Cegueira Deliberada nos crimes de lavagem de dinheiro, contudo constata-se que os contornos da Teoria ainda não foram aprofundados em nosso ordenamento, ocorrendo uma mera importação dos critérios desenvolvidos no direito estrangeiro.

\subsection{Lei de Lavagem de Capitais}

A Lei de Lavagem de Capitais, ํo 9613 de 1998, foi recentemente modificada pela lei $n=12.683$ de 2012, a nova legislação trouxe modificações significativas ao

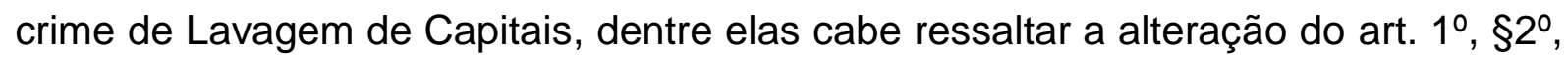
I, em que foi extinta da conduta a exigência do conhecimento pleno da ilicitude dos bens.

Com a modificação realizada no referido artigo, passou-se a ser possível a interpretação da modalidade de dolo eventual nos crimes de lavagem de capitais. Pierpaolo Bottini (2012) rechaça o dolo eventual na lavagem de dinheiro, contudo, entende que é possível equiparar a Teoria da Cegueira Deliberada ao dolo eventual, sendo possível assim sua aplicação no referido delito.

Este é o entendimento do ilustre professor Pierpaolo Bottini (2012):

Pessoalmente discordo da possibilidade de dolo eventual na lavagem de dinheiro. Mas, caso se admita a hipótese, algumas cautelas são necessárias. Antes de tudo, é fundamental notar que o dolo eventual, ainda que careça da vontade de resultado e da ciência plena da origem ilícita do bem, exige uma consciência concreta do contexto no qual se atua. Como ensina Roxin, não basta uma consciência potencial, marginal, ou um sentimento. Devese averiguar se o agente percebeu o perigo de agir, e se assumiu o risco de contribuir para um ato de lavagem. A mera imprudência ou desídia não é suficiente para o dolo eventual.

De acordo com os ensinamentos do ilustre professor e segundo os critérios já expostos neste trabalho, é possível a aplicação do dolo eventual no crime de 


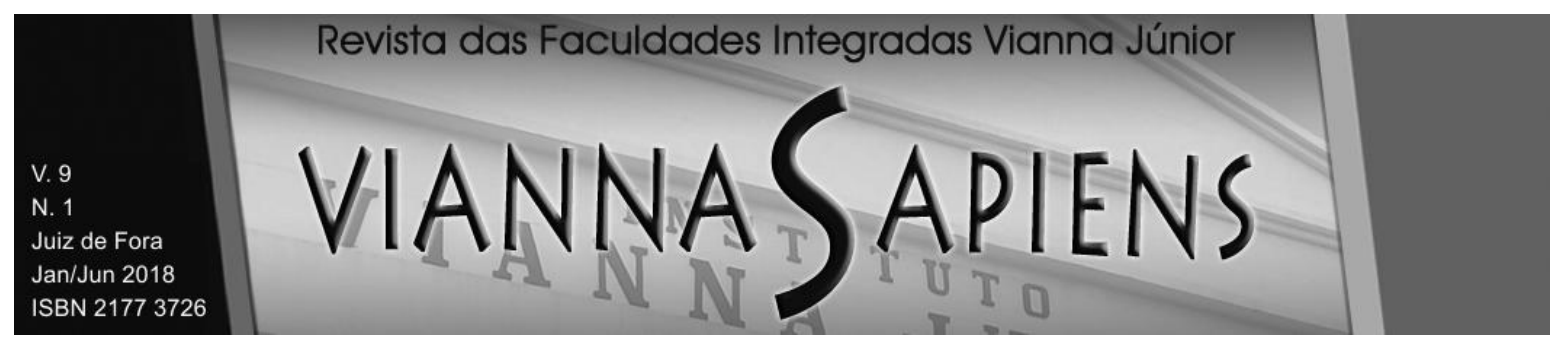

lavagens de capitais, caso estejam configurados os requisitos da Teoria da Cegueira Deliberada.

\subsection{Ação Penal 470}

A Ação Penal 470, conhecida como Mensalão, foi recebida pelo Supremo Tribunal Federal em 2007, dentre os quarenta denunciados, havia parlamentares e ministros, os quais foram denunciados pelos crimes de peculato, lavagem de dinheiro, corrupção ativa, gestão fraudulenta, dentre outras fraudes. Os envolvidos visavam à compra de suporte político e financiamento de campanhas eleitorais.

No decorrer da Ação Penal 470, com a aplicação da redação do art. 1ํㅡㄹ $\$ 2^{\circ}$, I da lei 9613/98 ainda sem alterações, colocou-se em discussão a possibilidade de aplicação do dolo eventual, segundo os critérios da Teoria da Cegueira Deliberada. Apesar dos entendimentos contrários ao dolo eventual na lavagem de dinheiro, a maioria admitiu a possibilidade de sua aplicação com a redação sem modificações.

Nesse sentido a Ministra Rosa Weber (2007, p. 1297)discorreu em seu voto no julgamento da Ação Penal 470:

Pode-se identificar na conduta dos acusados-beneficiários, especialmente dos parlamentares beneficiários, a postura típica daqueles que escolhem deliberadamente fechar os olhos para 0 que, de outra maneira, Ihes seria óbvio, ou seja, o agir com indiferença, ignorância ou cegueira deliberada.

Para o crime de lavagem de dinheiro, tem se admitido, por construção do Direito anglo-saxão, a responsabilização criminal através da assim denominada doutrina da cegueira deliberada (willful blindness doctrine). Em termos gerais, a doutrina estabelece que age intencionalmente não só aquele cuja conduta é movida por conhecimento positivo, mas igualmente aquele que age com indiferença quanto ao resultado de sua conduta.

De igual modo sustentou o ministro Celso de Mello (2007) em seu voto:

Admito a possibilidade de configuração do crime de lavagem de valores, mediante o dolo eventual, exatamente com apoio no critério 


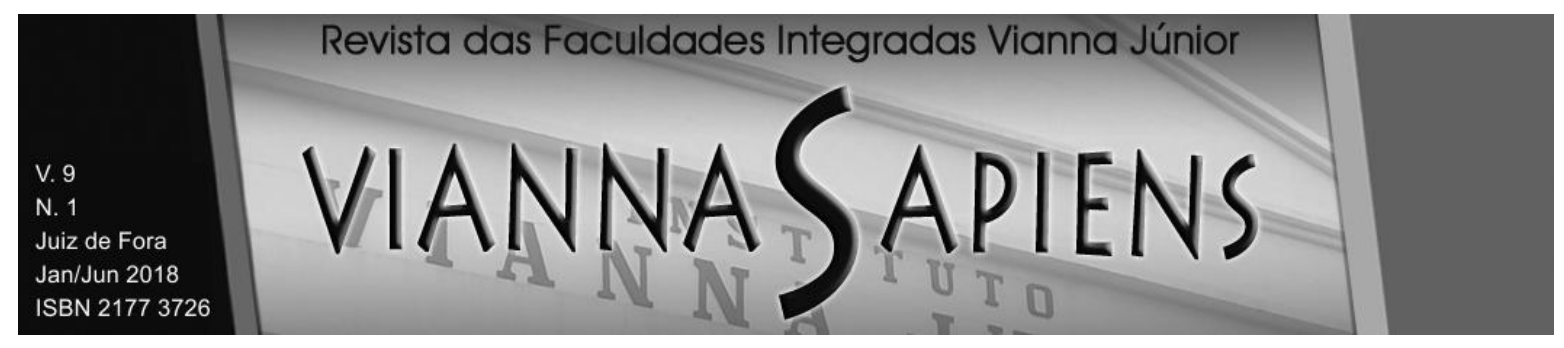

denominado por alguns como 'teoria da cegueira deliberada', que deve ser usado com muita cautela.

A menção à Teoria da Cegueira Deliberada na decisão da Ação Penal 470 pelo Supremo Tribunal Federal deu maior repercussão a Teoria, demonstrando sua aceitação pelo Tribunal Superior e possibilidade de aplicação em nosso ordenamento jurídico.

\subsection{O Caso do Furto ao Banco Central em Fortaleza}

O furto ao Banco Central de Fortaleza considerado o maior furto a banco da história do Brasil, ocorreu em agosto de 2005, sendo estimado o valor subtraído de aproximadamente 164 milhões de reais.

No dia seguinte ao furto os integrantes da quadrilha dirigiram-se a uma revendedora de carros e adquiriram 11 veículos, em espécie, com o dinheiro subtraído. Considerando a repercussão do caso e a conduta dos integrantes da quadrilha em adquirir 11 veículos, entendeu a Justiça Federal da $5^{\text {a }}$ Região no processo no 2005.81.00.014586-0 (2007), que um dos envolvidos na transação cometeu o delito de lavagem de dinheiro previsto na lei 9.613/98, com base na seguinte fundamentação:

Recorde-se, aqui e uma vez mais, os conceitos de dolo eventual e a doutrina da cegueira deliberada (willful blindness ou conscious avoidance doctrine) expostos anteriormente, no que pese entendermos que José Charles sabia da ocorrência do furto e, conseqüentemente, da origem do dinheiro, bem como as condutas dos proprietários da Brilhe Car José Elizomarte e Francisco Dermival ao não se absterem de tal negociação suspeita, nem comunicarem às autoridades responsáveis.

Da atuação de JOSÉ CHARLES MACHADO DE MORAIS no transporte de três veículos (com dinheiro oculto) e na entrega de oito veículos, dos onze veículos adquiridos na Brilhe Car, para membros da quadrilha. 


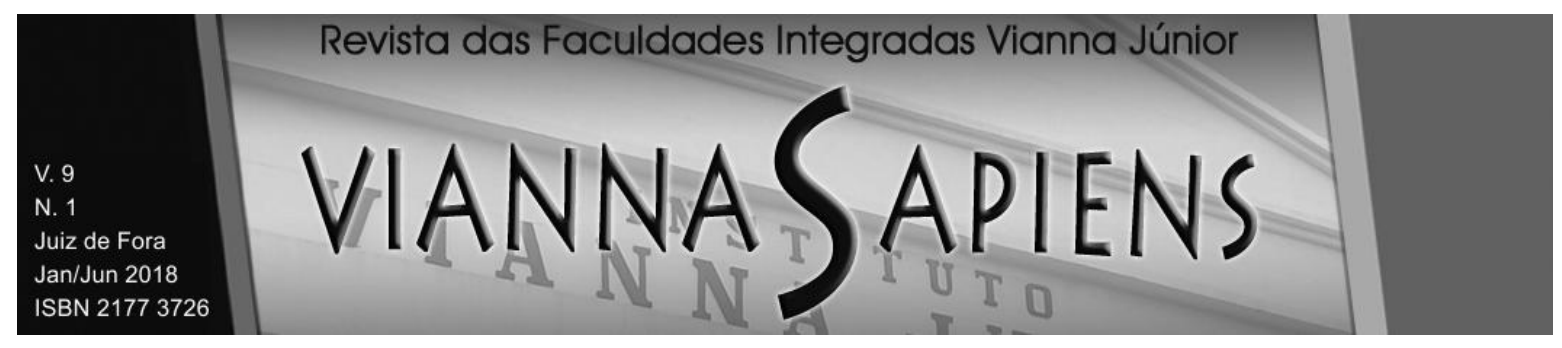

Fundado na Teoria da Cegueira Deliberada o juízo de primeiro grau condenou José Charles Machado de Morais pelo crime de lavagem de dinheiro, todavia, em segundo grau, o Tribunal Regional Federal reformou a sentença de primeiro grau, entendendo que a recepção da Teoria da Cegueira Deliberada traria uma espécie de responsabilização penal objetiva.

O Tribunal Regional Federal da 5 ${ }^{\underline{a}}$ Região na Apelação Criminal 5.520-CE (2008) firmou o seguinte posicionamento:

PENAL E PROCESSUAL PENAL. FURTO QUALIFICADO À CAIXAFORTE DO BANCO CENTRAL EM FORTALEZA. (...) TEORIA DA CEGUEIRA DELIBERADA (WILLFUL BLINDNESS). INEXISTÊNCIA DA PROVA DE DOLO EVENTUAL POR PARTE DE EMPRESÁRIOS QUE EFETUAM A VENDA DE VEÍCULOS ANTES DA DESCOBERTA DO FURTO. ABSOLVIÇÃO EM RELAÇÃO AO CRIME DE LAVAGEM DE DINHEIRO.

(...)

2.4- Imputação do crime de lavagem em face da venda, por loja estabelecida em Fortaleza, de 11 veículos, mediante o pagamento em espécie: a transposição da doutrina americana da cegueira deliberada (willful blindness), nos moldes da sentença recorrida, beira, efetivamente, a responsabilidade penal objetiva; não há elementos concretos na sentença recorrida que demonstrem que esses acusados tinham ciência de que os valores por ele recebidos eram de origem ilícita, vinculada ou não a um dos delitos descritos na Lei n. 9.613/98. O inciso II do PARÁGRAFO 2.. do art. 1.. dessa lei exige a ciência expressa e não, apenas, o dolo eventual. Ausência de indicação ou sequer referência a qualquer atividade enquadrável no inciso II do PARÁGRAFO $2^{\circ}$.

(...)

(PROCESSO: 200581000145860, ACR5520/CE, DESEMBARGADOR FEDERAL ROGÉRIO FIALHO MOREIRA, Segunda Turma, JULGAMENTO: 09/09/2008, PUBLICAÇÃO: DJ 22/10/2008 - Página 207). (Grifo nosso).

O Tribunal Regional Federal da $5^{\mathrm{a}}$ Região (2008) entendeu que não havia elementos suficientes que demonstrassem que os acusados tinham ciência da ilicitude dos valores recebidos, sendo assim, segundo o Tribunal, a condenação configuraria um caso de Responsabilidade Penal Objetiva. 


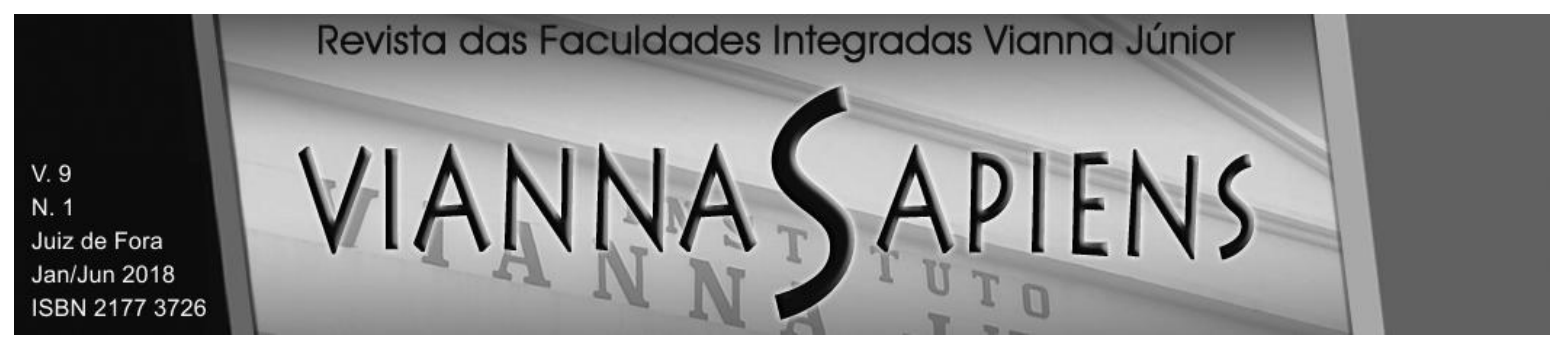

\subsection{Operação Lava Jato}

A Operação Lava Jato é a maior investigação de corrupção e lavagem de dinheiro realizada no Brasil, estima-se que os valores desviados sejam de bilhões de reais. O Ministério Público Federal apurou um imenso esquema criminoso,investigando e processando quatro organizações criminosas lideradas por doleiros, além de posteriormente constatar um esquema criminoso de corrupção envolvendo a Petrobrás.

Segundo dispõe o site do Ministério Público Federal ${ }^{6}$, o nome da Operação Lava Jato tem a seguinte explicação:

O nome do caso, "Lava Jato", decorre do uso de uma rede de postos de combustíveis e lava a jato de automóveis para movimentar recursos ilícitos pertencentes a uma das organizações criminosas inicialmente investigadas. Embora a investigação tenha avançado para outras organizações criminosas, o nome inicial se consagrou.

O Juiz Federal Sérgio Fernando Moro, nos autos da ação penal ํㅜ 501340559.2016.4.04.7000 (2017), também no caso Lava Jato, condenou Mônica Regina Cunha Moura e João Cerqueira de Santana Filho pelo crime de lavagem de dinheiro, sustentando sua decisão segundo os critérios da Teoria da Cegueira Deliberada:

Sem embargo do que mais se poderia escrever, é possível concluir que, desde que se tenha prova de que o agente tinha conhecimento da elevada probabilidade da natureza e origem criminosas dos bens, direitos e valores envolvidos nas condutas de ocultação e de dissimulação e de que ele escolheu agir e permanecer alheio ao conhecimento pleno desses fatos, mesmo tendo condições de aprofundar seu conhecimento, ou seja, desde que presentes os elementos cognoscitivo e volitivo, é possível e necessário reconhecer a prática do crime de lavagem por dolo eventual diante da previsão geral do art. 18, I, do CP e considerando a sua progressiva admissão pelas Cortes brasileiras.

\footnotetext{
${ }^{6}$ Disponível em: http://lavajato.mpf.mp.br/entenda-o-caso
} 


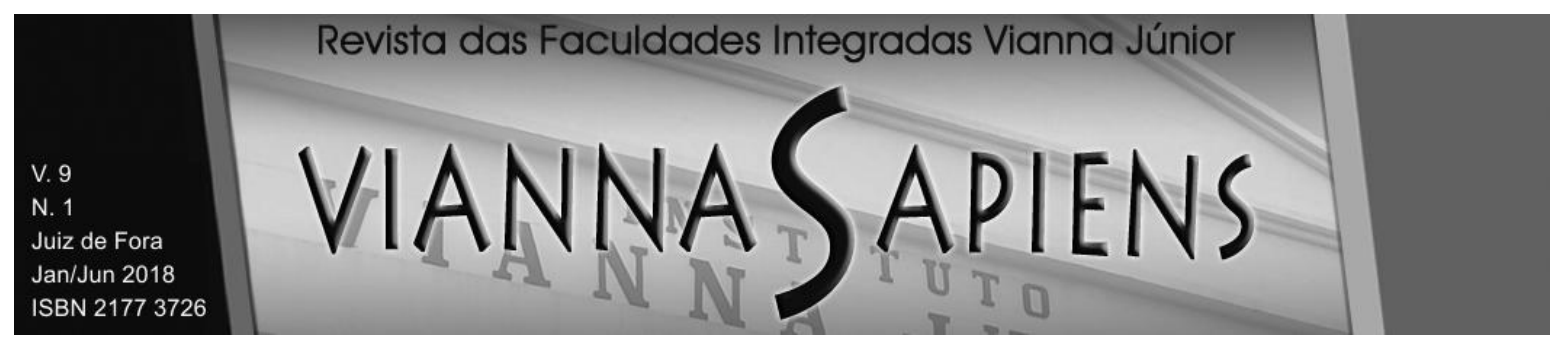

Ainda em sua fundamentação, o Juiz Federal nos autos da ação penal no 501340559.2016.4.04.7000 (2017), proferiu as seguintes palavras:

A postura de não querer saber e a de não querer perguntar caracterizam ignorância deliberada e revelam a representação da elevada probabilidade de que os valores tinham origem criminosa e a vontade realizar a conduta de ocultação e dissimulação a despeito disso.

Encontram-se, portanto, presentes os elementos necessários ao reconhecimento do agir com dolo, ainda que eventual, na conduta de Mônica Regina Cunha Moura e de João Cerqueira de Santana Filho.

Segundo, tinham Mônica Regina Cunha Moura e de João Cerqueira de Santana Filho presentes os riscos concretos, de que se tratava de valores oriundos de crimes de corrupção, não só pelas circunstâncias ilícitas da transação, com adoção de expedientes sofisticados de ocultação e dissimulação, mas também pelo exemplo da Ação Penal 470. Mesmo tendo eles presentes esses riscos, persistiram na conduta delitiva, ou seja, receberam os valores, com ocultação e dissimulação. Tinha ainda condições não só de recusar o pagamento na forma feita, mas de aprofundar o seu conhecimento sobre as circunstâncias e a origem do dinheiro, tendo preferido não realizar qualquer indagação a esse respeito.

Deste modo, o Juiz Federal Sérgio Moro (2017) entendeu que os referidos réus agiram com dolo ao celebrarem um contrato de prestação de serviços falso a fim de amparar fraudulentamente os depósitos, além de não terem aprofundado seus conhecimentos sobre a origem do dinheiro recebido.

\subsection{A (im) possibilidade de aplicação da Teoria da Cegueira Deliberada no Direito Penal Brasileiro}

Consoante abordado anteriormente a Teoria da Cegueira Deliberada não tem sua aplicação pacificada em nossos Tribunais, sendo necessário aprofundar seus contornos segundo o Direito Brasileiro, tendo em vista que sua aplicação atualmente baseia-se na importação de critérios do direito estrangeiro.

Na opinião de Vinicius Arouck (2017): 


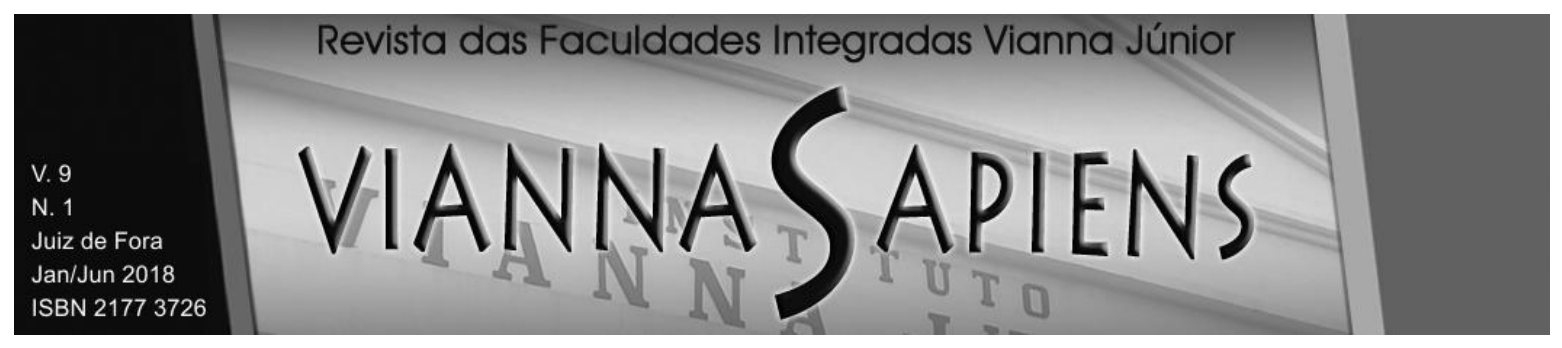

Destarte, nada impede que haja o amadurecimento dessa Teoria perante os Tribunais brasileiros, todavia, é indiscutível que deve haver alteração legal que dê sustentáculo normativo para sua implementação no ornamento jurídico pátrio. Não se nega, porém, que, em que pese existirem inúmeros problemas extralegais presentes na Teoria da Cegueira Deliberada, trata-se de uma interessante teoria que deve ser mais bem estudada para que em um futuro próximo se promova uma melhor delineação de suas características e consequências à luz da Constituição Federal, a fim de que seja possível a utilização de sua eficiência na incessante luta contra a impunidade.

A Teoria da Cegueira Deliberada surge com o intuito de dar maior efetividade à persecução penal, todavia sofre inúmeras críticas no ordenamento jurídico brasileiro, conforme bem mencionado pelo professor Vinicius Arouck (2017), a teoria necessita ser mais bem estudada, promovendo uma melhor delineação de suas características, possibilitando sua aplicação em nosso ordenamento e fazendo com que não se esbarre nos casos de Erro de Tipo ou de Responsabilidade Penal Objetiva.

\section{CONCLUSÃO}

Vimos no desenrolar deste trabalho acadêmico que a Teoria da Cegueira Deliberada é uma doutrina recente em nosso ordenamento jurídico e ainda pouco debatida em nossa doutrina e jurisprudência.

A Teoria tem sido recentemente aplicada em vários casos em nossos Tribunais, como no processo do Furto ao Banco Central, na Operação Lava Jato e na Ação Penal 470, popularmente conhecida como Mensalão, sendo inclusive mencionada pelos ministros do Supremo Tribunal Federal, contudo ainda há uma grande controvérsia quanto a sua aplicação.

De acordo com o que foi exposto, a Teoria surgiu no direito estrangeiro, fruto de entendimentos jurisprudenciais ingleses e com ampla aplicação no ordenamento norte-americano, com origem na Common Law. 


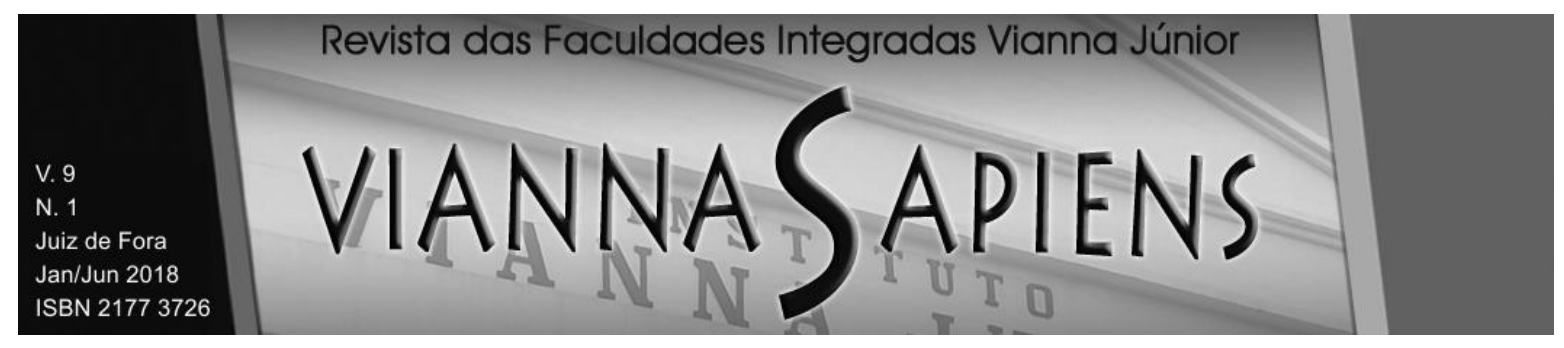

Diante das lacunas na lei e da necessidade de punição de agentes que se utilizam de mecanismos para alegar a ignorância deliberada, a Teoria da Cegueira Deliberada surge como importante ferramenta para o Poder Judiciário.

A possibilidade de aplicação da Teoria, principalmente nos casos de lavagem de dinheiro, trouxe grande avanço para o direito brasileiro, permitindo o combate ao crime de corrupção, crime organizado, dentre outros.

A polêmica quanto a possibilidade de aplicação da Teoria da Cegueira Deliberada no âmbito do dolo eventual se mantém, tendo em vista sua recente importação para nosso ordenamento, gerando inúmeras críticas e controvérsias, como a caracterização do Erro de Tipo e da Responsabilidade Penal Objetiva.

É de extrema importância que o estudo da Teoria se aprofunde, delimitando seus critérios, esquivando-se de uma aplicação com base em mera suposição de ignorância deliberada, o que causaria inevitavelmente a configuração da Responsabilidade Penal Objetiva.

Deste modo, o presente trabalho buscou abordar quanto a possibilidade de aplicação da Teoria da Cegueira Deliberada no Direito Penal Brasileiro, esclarecendo sua origem histórica, seu conceito, suas delimitações, o dolo no direito penal brasileiro e apontando os casos em que a Teoria já foi aplicada em nossos Tribunais.

Diante de todo o abordado, muitas críticas e controvérsias foram constatadas na aplicação da Teoria da Cegueira Deliberada, sendo ainda necessário um aprofundamento por parte de nossa doutrina e jurisprudência. Ainda assim é possível concluir que a Teoria é uma realidade na Jurisprudência Brasileira, sendo aceitável sua aplicação quando constatada a existência dos requisitos estudados neste trabalho acadêmico. 


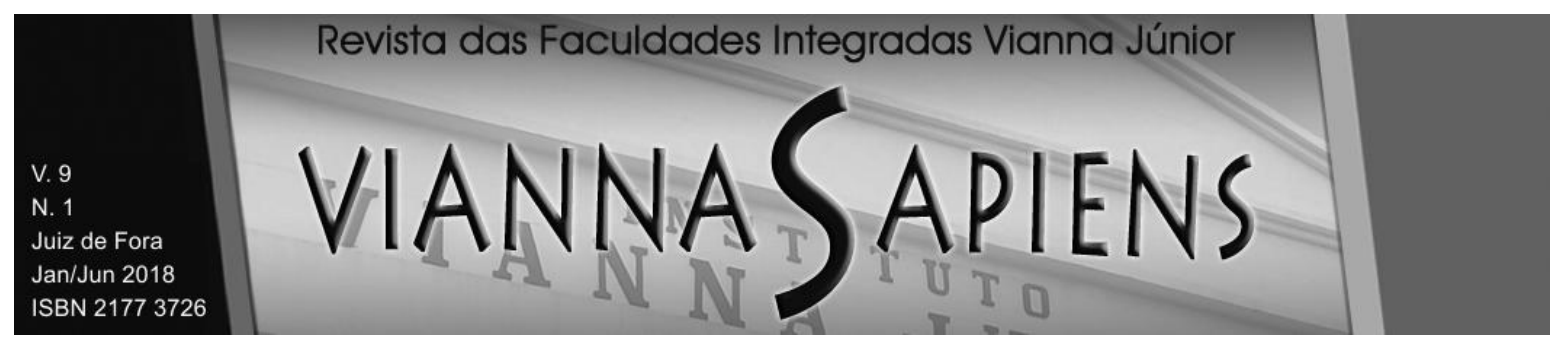

THE (IM) POSSIBILITY OF APPLYING THE THEORY OF DELIBERATE BLINDNESS IN BRAZILIAN CRIMINAL LAW

\begin{abstract}
This article aims at the study of the Theory of Deliberate Blindness and its possibility of application in the Brazilian legal system. At the beginning, the objective is to clarify the historical origin, nomenclatures, concepts and delimitations of the Theory. After these considerations, there is a discussion about malice in Brazilian criminal Law and the existing controversies about the theory in thes cope of non-existence of malice. Finally, a brief description was sought of the Money Laundering Law, with the analysis of the main cases in which the Theory was applied in our Courts. In conclusion, we understand the possibility of applying the Deliberate Blindness Theory in Brazilian Criminal Law, by observing the requirements addressed.
\end{abstract}

KEY-WORDS: THEORY OF DELIBERATE BLINDNESS .EVENTUAL MALICE. MONEY LAUNDERING LAW . BRAZILIAN CRIMINAL LAW

\title{
REFERÊNCIAS
}

ABRAMOWITZ, Elkan Abramowitz \& BOHRER, Barry A. Conscious Avoidance: A Substitute for Actual Knowledge? New York Law Journal. Disponível em: https://www.maglaw.com/publications/articles/2007-05-01-conscious-avoidance-asubstitute-for-actualknowledge/_res/id=Attachments/index=0/07005070001Morvillo.pdf. Acesso em 2 de agosto de 2017. 


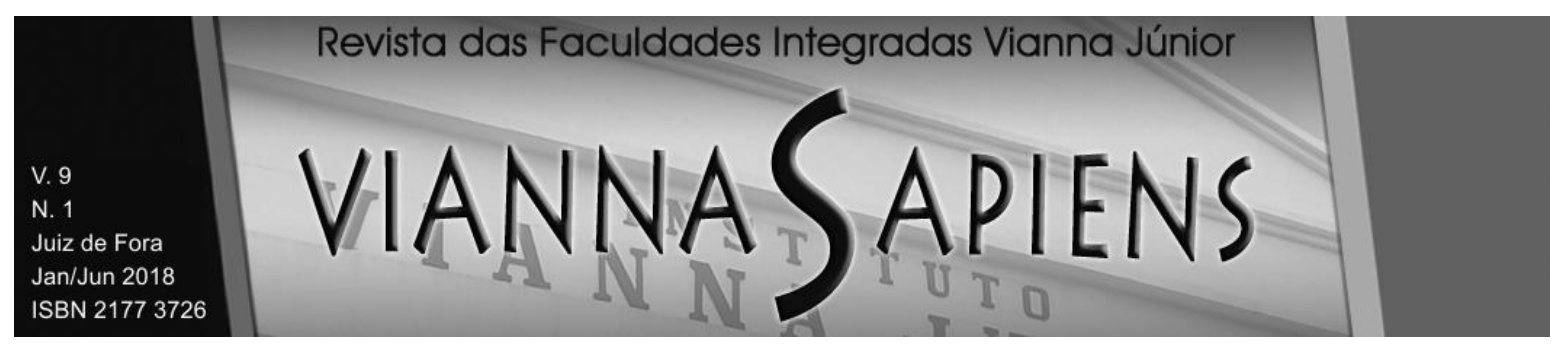

AROUCK, Vinicius. A Teoria da Cegueira Deliberada e sua aplicabilidade no ordenamento jurídico pátrio. Empório do Direito: 2017. Disponível em: http://emporiododireito.com.br/tag/teoria-da-cegueira-deliberada/\#_ftn43. Acesso em 5 de agosto de 2017.

BITENCOURT, Cezar Roberto. Tratado de direito penal : parte geral 1. $23^{\mathrm{a}}$ edição revista, ampliada e atualizada. São Paulo: Saraiva, 2017.

BOTTINI. Pierpaolo Cruz. A cegueira deliberada no julgamento da Ação Penal 470. Revista Consultor Jurídico: 2013. Disponível em: http://www.conjur.com.br/2013-jul-30/direito-defesa-cegueira-deliberada-julgamentoacao-penal-470. Acesso em 5 de agosto de 2017.

BOTTINI. Pierpaolo Cruz. A tal cegueira deliberada na lavagem de dinheiro. Revista Consultor Jurídico: 2012. Disponível em: http://www.conjur.com.br/2012-set04/direito-defesa-tal-cegueira-deliberada-lavagem-dinheiro. Acesso em 5 de agosto de 2017.

BRASIL. Justiça Federal de Primeiro Grau da 5a Região. 11ª Vara da Seção Judiciária do Ceará. Ação Penal no 2005.81.00.014586-0. Juiz Federal Danilo Fontenelle Sampaio. Data de Julgamento: 28 de junho de 2007. Disponível em: http://www.jfce.jus.br/consultaProcessual/resimprsentintegra. asp?CodDoc=2177598.

BRASIL. Justiça Federal de Primeiro Grau da 4 ${ }^{\mathrm{a}}$ Região. 13aㅡ Vara Federal de Curitiba. Ação Penal no 501340559.2016.4.04.7000/PR. Juiz Federal Sérgio Fernando Mouro. Data do Julgamento: 02 de fevereiro de 2017. Disponível em: http://www.mpf.mp.br/para-o-cidadao/caso-lava-jato/atuacao-na-1ainstancia/denuncias-do-mpf/documentos/sentencasantana.pdf.

BUSATO, Paulo César. Direito penal: parte geral, v. 1. $3^{\underline{a}}$ edição revista, atualizada e ampliada. São Paulo: Atlas, 2017.

BRASIL. Supremo Tribunal Federal. Ação Penal no 470/MG - Plenário. Relator: ministro Joaquim Barbosa. Disponível em: ftp://ftp.stf.jus.br/ap470/InteiroTeor_AP470.pdf. 


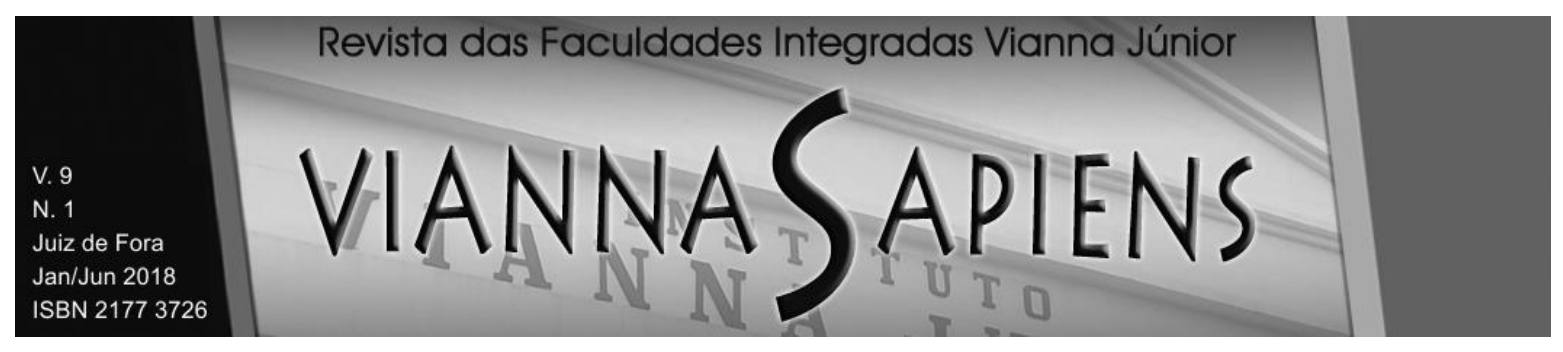

BRASIL. Tribunal Regional Federal da 5 $5^{\text {a }}$ Região. Apelação Criminal 5520-CE. Ementa: Furto Qualificado à Caixa-Forte do Banco Central em Fortaleza. Relator: Desembargador Federal Francisco Barros Dias. Disponível em: http://www.trf5.jus.br/archive/2008/10/200581000145860_20081022.pdf.

CABRAL, Bruno Fontenele. Breves comentários sobre a teoria da cegueira deliberada (willful blindness doctrine). Revista Jus Navigandi, ISSN 1518-4862, Teresina, ano 17, n. 3193, 29 mar. 2012. Disponível em: <https://jus.com.br/artigos/21395>. Acesso em 3 de agosto de 2017.

CALLEGARI, André Luis; WEBER, Ariel Barazzetti. Lavagem de Dinheiro. São Paulo: Atlas, 2014.

CALLEGARI, André Luis; WEBER, Ariel Barazzetti. Lavagem de Dinheiro. $2^{\mathrm{a}}$ edição. São Paulo: Atlas, 2017.

CAPEZ, Fernando. Curso de direito penal, volume 1, parte geral: (arts. 10 a 120). 20aㅡ edição. São Paulo: Saraiva, 2016.

CHARLOW, Robin. Wilful Ignorance and Criminal Culpability. Maurice A. Deane School of Law at Hofstra University, Nova York, 1992.

CUNHA, Rogério Sanches. Manual de direito penal: parte geral (arts. 10 ao 120). 4ª edição revista, ampliada e atualizada. Salvador: JusPODIVM, 2016.

GEHR, Amanda. A Aplicação da Teoria da Cegueira Deliberada no Direito Penal Brasileiro. Curitiba: 2012. Disponível em:

http://acervodigital.ufpr.br/bitstream/handle/1884/31107/AMANDA\%20GEHR.pdf?se quence=1. Acesso em 5 de agosto de 2017 .

JUNIOR, Miguel Reale. Instituições de Direito Penal: parte geral. 4⿳亠丷a edição revista e atualizada. Rio de Janeiro: Forense, 2012. 


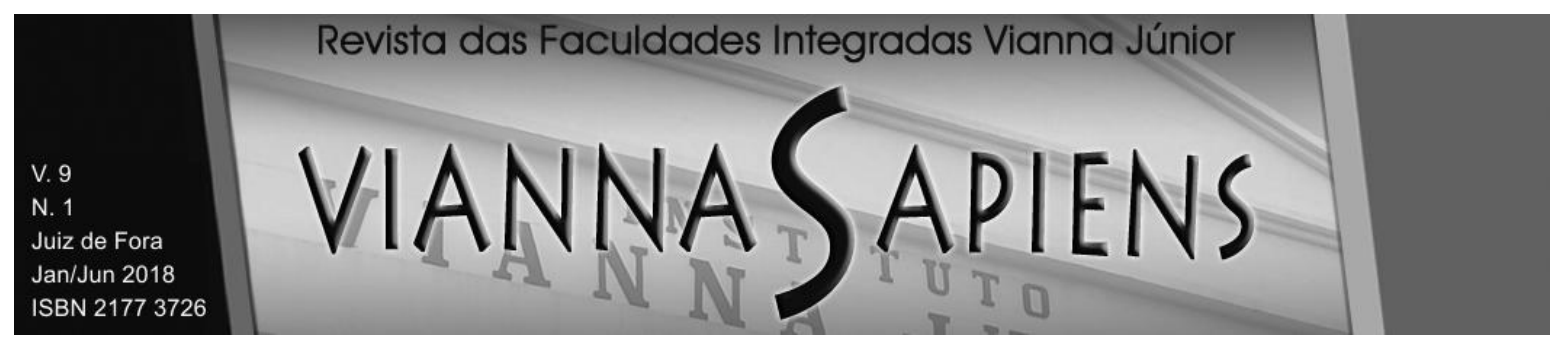

MONTEIRO, Taiana Alves. Aplicação da Teoria da Cegueira Deliberada no Brasil. Revista Consultor Jurídico: 2009. Disponível em: http://www.conjur.com.br/2009-set-28/necessario-dolo-especifico-caracterizacaocorrupcao-eleitoral. Acesso em 5 de agosto de 2017.

RAGUÉS I VALLÈS, Ramon. La ignorancia deliberada en derecho penal. Barcelona: Editora Atelier, 2007.

RAGUÉS I VALLÈS, Ramon. Mejor no saber, Sobre la doctrina de la ignorância deliberada em Derecho penal. Barcelona: Universitat Pompeu Fabra, 2013.

ROBBINS, Ira P. The Ostrich Instruction: Deliberated Ignorance as a Criminal Mens Rea.Journal of Criminal Law and Criminology, Chicago, 1990.

Recebido em 02/05/2018

Publicado em 13/08/2018 